\title{
Hard and Soft Power
}

\section{Approaches to Armed Conflicts:}

\section{The United States in Iraq and Russia in Syria}

\section{Greg Simons}

\author{
Greg Simons \\ Uppsala University, Uppsala, Sweden \\ Institute for Russian and Eurasian Studies \\ Associate Professor, Researcher; \\ Humanitarian Institute at the Urals Federal University, Yekaterinburg, Russia \\ Leading Researcher; \\ Diplomatic Academy of the Russian Federation, Moscow, Russia \\ Associated Researcher. \\ ORCID: 0000-0002-6111-5325 \\ ResearcherID: A-6514-2019 \\ Scopus Author ID: 14322163700 \\ Academia.edu: https://uppsala.academia.edu/GregSimons \\ E-mail:greg.simons@ires.uu.se \\ Address: IRES, Box 514, SE-751 20 Uppsala, Sweden \\ DOI: $10.31278 / 1810-6374-2021-19-2-86-110$
}

\begin{abstract}
Armed conflicts are generally associated with the use of hard power for coercing and forcing an opponent to do something against its will in a situation where war is an extension of politics. However, there are many scholarly observations about the important role of soft power in armed conflicts, the interaction between hard and soft power, and the effects on one another within the framework of an armed conflict. This paper explores
\end{abstract}


two specific armed conflicts, the 2003 U.S.-led military intervention in Iraq and the 2015 Russian intervention in Syria. Various aspects of hard and soft power approaches are discussed, and the outcome of military operations for the national soft power potential is analyzed. The results of the study show that whereas the Iraq War came as a disaster for the U.S., the military operation in Syria-despite dire predictions - created strengths and opportunities for Russia in international relations.

Keywords: Syrian war, Russia, military intervention, soft power, hard power, Iraq War, United States.

rmed conflict as a form of violent political activity is normally
associated with the use of hard power (Matlary, 2006).
However, recent research has revealed that there are also other approaches to armed conflicts that go beyond kinetic activities of hard power (Wagner, 2005). The list of 'power' terms associated with the junction of foreign policy and armed conflicts includes 'soft power', 'hard power,' and 'smart power' (Gray, 2011; Kounalakis and Simonyi, 2011; Select Committee, 2014). Political analysts say that hard power is becoming increasingly problematic as a foreign policy tool and soft power is becoming more valuable. Also, there is a clear tendency towards mixing hard and soft power components into smart power to complement each other's strengths and overcome their weaknesses (Wagner, 2014). However, relatively little attention is paid to how hard and soft power interact and become interrelated in armed conflicts, and what comparable effects of their application are.

In order to identify and analyze the effects of and interactions between hard and soft power in contemporary armed conflicts, this article focuses on two case studies-the 2003 U.S. intervention in Iraq and the 2015 Russian intervention in Syria. The U.S. campaign in Iraq in some regards set the benchmark for resorting to deception to start a war (Bennett, Lawrence and Livingston, 2007). This was a campaign of "shock and awe" in the militarized use of hard power aimed at regime change (Zollmann, 2017). The result severely damaged the U.S. image - and hence its soft power-and its subsequent foreign 
and security policy options. Russia's military engagement in the Syrian war in 2015, which involved a mixture of hard and soft power tools for ensuring regime stability, drew a negative response from the West, where it was taken with suspicion and imaginary links. Dire predictions were made about its long-term effects on Russia's future soft power and reputation (Dannreuther, 2015), which have not materialized, though.

This article falls into several sections. The first one describes the methods used for collecting the empirical data and its analysis. The second section looks at the roles and effects that hard and soft power have in armed conflicts. The third section describes the political background against which the U.S. set its foreign and security policy goals in Iraq and how it sought to achieve them. This is followed by an analysis of the use of hard power by the U.S. in Iraq and its effects on its soft power and interests. The following sections examine the specific events and circumstances that led to Russia's direct involvement in Syria, and the role of hard power in the Syrian armed conflict. Finally, the article discusses the role of soft power in contemporary armed conflicts.

This paper is based on the complex approach to textual analysis, which includes content analysis (quantifications of different elements in a text), argumentation (the structure of argumentation used), and qualitative analysis of relevant ideas (with a focus on foreign and security policy) (Boréus and Bergström, 2017, pp. 7-9). This approach was expected to reveal the ontology and epistemology of reactions to mass-mediated textual depictions of the U.S. and Russian military engagements in the Iraqi and Syrian conflicts, respectively. The objects of study include power, people, policy, oppression and freedom, war and peace, etc. (Boréus and Bergström, 2017, pp. 1-2). It is presumed that mass media texts contextualize the relationships according to perceived and projected power in a constructed social world order, such as the relationship between soft and hard power, legitimate and illegitimate practices, projection and reality.

To create an indicative study, a qualitative approach to data analysis was applied to sizable material. The samples were collected using Google general search and Google Scholar search. The following search terms were entered: hard power in conflict; soft power in conflict; U.S. 
hard and soft power in Iraq; Russian military intervention in Syria; and Russian hard and soft power in Syria. By scrolling through the hits, some 80 articles were manually selected in accordance with their closeness to the topics of primary interest of this paper-the 2003 U.S.-led military intervention in Iraq and the 2015 Russian military intervention in the Syrian war.

There are some strengths and weaknesses in using this comparative method of analysis. One weakness is that the study focuses entirely on the actions and intentions of the U.S. in Iraq and of Russia in Syria and therefore excludes other positive and negative influences on the outcome of these campaigns for the U.S. and Russia. For example, Iran's approach contributes to Russia's broader goals in Syria, but is not facilitating U.S. goals in Iraq. Similarly, the role of the U.S. in obstructing the resolution of the Syrian conflict that aims to preserve the Assad regime is not discussed. However important, these and other influences are beyond the scope of this paper.

It may be argued that the comparison of the effects of the use of soft and hard power by the U.S. in Iraq in 2003 and by Russia in Syria in 2015 is questionable as these cases are dissimilar, or that the comparative value of the ends is doubtful. However, this paper focuses on the means, not on the ends. Using other groups of cases also carries risks; for example, going by more chronologically comparable cases of the U.S. in Iraq in 2014 and Russia in Syria in 2015 would not be a good fit. The U.S. intervention in Iraq in 2014 was necessitated by the regional instability caused by the American invasion and occupation of this country in 2003. Furthermore, both cases studied here were interventions intended to serve as game changers in the MENA region, to increase U.S. influence in the former case and Russian influence at the expense of the U.S. in the latter case. Both examples of intervention appear as regional (and perhaps even global) force projections, but with different ratios and approaches to the use of soft and hard power.

\section{HARD AND SOFT POWER IN ARMED CONFLICTS}

Kounalakis and Simonyi maintain that "power in international relations must be seen as spectral, with hard-hard power on one end and soft- 
soft power on the other" (2011, pp. 13-14). Bially Mattern believes that "soft power should not be understood in juxtaposition to hard power but as a continuation of it by different means." She argues that "in the context of world politics it makes far more sense to model attraction as a relationship that is constructed through representational force-a nonphysical but nevertheless coercive form of power" enabled with carefully crafted language (2005, p. 583).

To place the use of hard and soft power within armed conflict, it is necessary to define these terms and their use in politics and international relations. Soft power as a concept is associated with Joseph Nye, its original meaning within the context of world politics being about a nation's ability to attract and persuade, while that of hard power is to apply it for coercion. Hard power makes use of a country's military or economic might to force another country to do something that is against its will. Soft power makes use of a country's culture, political ideals, and policies as a basis for its attractiveness, and attempts to persuade an actor to adopt a certain stance or take action through non-coercive means (Nye, 2004). These are two seemingly distinct concepts that run separate paths.

Concepts of hard and soft power can be regarded as two poles on a continuum of power. They also imply different ideas, interactions, and institutions used as foreign policy tools in the fields of politics, security, and economy. Ideally, hard power strategies focus on military intervention, coercive diplomacy, and economic sanctions used to enforce national interests resulting in confrontational policies vis-àvis neighboring countries. In contrast to this, soft power strategies emphasize the importance of common political values, peaceful means for conflict management, and economic cooperation for achieving common solutions (Wagner, 2005, p. 2).

There are attempts to conceptualize the transformation of one type of power into the other-hard power to soft power and vice versa. One such conceptualization is the idea of 'hard' application of soft power, which implies building up the capability of a country's political and military power potential for strategic use of force for a "good" cause. In some regards, this is a development of the coercive diplomacy of 
using military force (Matlary, 2006; Gray, 2011). As such, the concept tends to straddle both forms of power that are ostensibly used in the name of protecting human security. However, this approach raises the issue of legitimacy, which, in turn, involves the questions of ethics and international law, together with the assumption that human security trumps state security (Matlary, 2006, p. 113). The era of "humanitarian wars" tends to disregard the relevance of the Westphalian system in the rhetorical pursuit of human security.

The above reasoning implies a possibility of interchanging and exchanging the aspects of soft and hard power in the pursuit of foreign policy and security goals. One of the criticisms of the soft power versus hard power debate within the realm of foreign policy is that these two camps do not integrate their positions into a single framework sufficiently enough for advancing national interests (Wilson, 2008, p. 110). However, there is also a view that one form of power can enable the other one. For example, Linus Hagström from the Swedish Defence University argues that "soft power is not at all at odds with hard power in international politics. Rather, the use of military violence tends to be preceded and legitimized by strategies for soft power" (Frykskog, 2019).

There are criticisms of these concepts of power and their application in foreign policy as being too U.S.-centric. This points to Wilson's warning (2008) to avoid the "cookie cutter" approach in operationalizing hard and soft power, that is, to take the specific environmental context into account. In the context of this article the terms 'hard power' and 'soft power' are defined as follows: hard power is the use of kinetic military or some other form of force to subdue and compel an opponent against its will to do the bidding of the user of that force. Soft power is the use of non-kinetic force to persuade an opponent to adopt a certain policy stance or perspective.

In the context of an armed conflict, hard and soft power are very complex in nature and application and should not be viewed as a binary but rather as a spectral phenomenon. Furthermore, the use of soft and hard power in an armed conflict seems to be influenced by the contextual positioning of an actor considering their use in the international system. In the context of this comparative study, 
the U.S. is viewed as the global unipolar hegemon (albeit in relative decline) having vast hard and soft power resources at its disposal that no other country can tangibly match. Therefore, it is presumed that there are less constraints for the U.S. to use hard power which can bring quicker results for achieving foreign policy and security goals. Russia is positioned as a challenger to U.S. global hegemony in the international system; it possesses far less hard and soft power resources, which creates a greater number of constraints on the use of hard power. Therefore, a more careful and considered approach to the application of hard and soft power is needed, with a greater emphasis placed on the medium- to long-term effects of the use of this power for settling foreign-policy and security problems.

This article shows that the effects of the use of hard and soft power on foreign and security policy go well beyond the cases that are the focus of this research. The use of the soft-hard power mix can cause a lot more meaningful effects in terms of creating opportunities and obstacles for foreign policy in the future. After the Iraq War the U.S. has been constrained domestically and internationally, while Russia has gained various opportunities as a result of its involvement in the Syrian conflict, such as the Astana Accords and expanded diplomatic opportunities in the MENA region and beyond (Morozov and Simons, 2019). This means that the concrete outcome of a conflict and its resolution or lack of resolution is not the most important factor, much more significant is the long-term effect that such military operations may have for foreign and security policy options of the actor(s) in the future.

\section{THE U.S. ROAD TO IRAQ (2003)}

After the attacks on the U.S. mainland in September 2001, the foreign and security policy of "fighting terrorism" through the strategic policy brand of the Global War On Terrorism (GWOT) gave it greater operational freedom of choice (Bennis, 2003). This situation enabled the U.S. to accumulate soft power from the political capital and a sense of legitimacy from the attacks to broaden the conflict should it choose to do so. The road was relatively short-18 months, from the 
September attacks in 2001 till the U.S.-led invasion of Iraq in March 2003. A great deal of information operations and influence activity was conducted through mass media for national and international audiences (Bennett, Lawrence and Livingston, 2007; Simons, 2008; Zollmann, 2017). Several points could be seen in the role of mass media, information campaigns, and politics in paving the way for war.

Retrospectively, there was a clear cleavage between the publicly stated defensive reasons for invading Iraq and the private or personal political reasons (Hinnebusch, 2007). The argumentation was that the George Bush administration needed to go for a pre-emptive war in order to ward off the threat of the alleged presence of weapons of mass destruction (WMD) and terrorist links between Iraqi leader Saddam Hussein and Al Qaeda (Western, 2005, pp. 175-219). The used communication strategy involved a great deal of deception to elevate the American public's fear of the "threat" in order to engineer its consent to war (Hinnebusch, 2007). This obscured the private political reasons for the invasion of Iraq, and the circumstances that enabled this to happen. "By controlling the agenda and timing of the debate, the hardliners gradually introduced the concept of regime change and pre-emptive war over a period of several months and then timed the escalation of their campaign to coincide with the highly emotional first anniversary of the September 11 attacks, to maximize the appeal" (Western, 2005, p. 179).

According to Payne (2005), mass media is an instrument of war; individual battles are determined by military might and skill, but wars are won and lost through politics. Many analysts agree that instead of playing an independent role or that of the fourth estate, mass media and journalists tend to support the policy of war when an "enemy threat" is identified and pointed to by the political elite (Zollmann, 2017).

Think tanks also face difficulties with conducting an unbiased analysis during international crises. When relations are strengthened, the space for discourse and diverse opinion narrows, and when a conflict turns into a hot phase, researchers expressing critical assessments may be viewed by their governments as national traitors (Tsygankov et al., 2021). 
The Iraq War of 2003 was no exception. The press covered the issue of the threat allegedly coming from Iraq not only uncritically in terms of how they treated information sources but echoed the official line that demonized Hussein and hyped the threat of connection between WMD and terrorism. Many researchers agree that the press actually failed their public duty to adequately present balanced news reports concerning the call for war in Iraq, its actual results and consequences (Bennett, Lawrence and Livingston, 2007). The close relationship between the media and politics produced informational dominance in the mainstream global information sphere that was used to shape the cognitive ground for the target audience's consent to war.

By exploiting the international community's sympathy for the U.S. after the 9/11 attacks and the U.S. public's fear of further attacks the Bush administration was able to elicit emotional response from the target audiences. In this respect the role of the political capital and the semblance of legitimacy were used as a source of soft power to enable the operationalization of hard power means to achieve political goals.

\section{U.S. HARD POWER OF "SHOCK AND AWE" IN IRAQ}

The long history of U.S. policies in the Middle East has been marked by alternating cycles of the use of soft and hard power, be it championing "democracy" in the region or the use of military force in managing regime change (Gianotta, 2020). These cycles dependent on diverse circumstances, such as the personality of regional leaders and the urgency of policy imperatives. Bially Mattern (2005, p. 583) notes that "since 9/11, the Bush administration has consciously refashioned the American role in world politics from that of benign hegemon to that of neo-imperialist. It has abandoned the 'soft power' politics of constructive engagement and multilateralism in favor of the 'hard power' politics of the war on terrorism." This was clearly seen in the approach to regime change in Iraq in 2003.

There were attempts to play down the use of deception for engineering public consent to the need and urgency for the use of hard power in Iraq as a "defensive" reaction. Parallels can be found in Bially Mattern's (2005) idea of "representational force" applied to the domestic 
and foreign public for the purpose of deceptive operationalization. There were also attempts to narrate the illegal invasion as a necessary "humanitarian intervention." However, Roth (2006) insists that this justification cannot be applied to the Iraq War of 2003 because it was not meant to stop war crimes, non-military options had not been exhausted by the time of the attack, there was no attempt to secure a mandate from the United Nations, and the harm done by the regime change far exceeded the good. Of course, the abuse of the humanitarian intervention narrative in Iraq weighs negatively on any possible future attempts to invoke the concept (Moses, Bahador and Wright, 2011). Steinberg states that "the idea that these goals could be achieved through a naked assertion of U.S. primacy was fundamentally flawed" (2008, p. 161). The point is that the U.S. had no check and balance and calculated there was nothing to stop it from using hard power and nothing to motivate it from choosing the long-term and difficult application of soft power to achieve the goals.

Following the disaster that resulted from the ill-considered and hastily executed display of "shock and awe" hard power in Iraq and the predictable negative consequences (such as the rise of Islamism and insurgency) there was an increasing call for reconsidering the approach to such foreign policy operations. One of the calls was for soft power to be pursued as a supplementary means to military (kinetic) operations in Iraq and the wider Muslim world (Bose and Lyons, 2015). Nye (2003) concluded that the overwhelming nature of U.S. military power in Iraq demonstrated that the world was out of balance. He also argued that soft power was ignored as the policy makers and practitioners that championed hard power saw this as a sign of weakness. "Inadequate attention to soft power was detrimental to the hard power the United States could bring to bear in the early days of the war" (Nye, 2003, p. 67). This led to the belief that the U.S. was losing its soft power potential unnecessarily and delivering soft power potential to adversaries and competitors (Munslow, 2009). This in turn has called for the need to embark upon re-establishing U.S. soft power and its potential for long-term perspectives in international relations (Hyde-Smith, 2007). 
The political public consensus to go to war led to the flawed decision as tactical military and political goals were identified, but little thought was given to long-term political implications. The decision resulted in a costly drawn-out armed conflict that took a heavy toll on human lives and resources, and in the loss of public trust in U.S. policies that had led to a seemingly endless war with no sign of success or a decent exit from the situation. The short-sighted thinking in the line of concentrated application of hard power for achieving foreign policy goals created several negative trends that have destabilized U.S. interests, rather than securing them (Baker et al, 2006). One of the motivations for rethinking the use of soft power in Iraq is its potential to counter Russia's influence in the country (Borshchevskaya, 2019). Therefore, the role of soft power is seen as a mechanism of obstructive foreign policy, a persuasive form of counter-attraction. Iraq has also proved to be a significant constraining factor in subsequent U.S. regime change operations, such as that in Syria.

\section{THE ROAD TO RUSSIA'S DIRECT INTERVENTION IN SYRIA}

Russia's foreign and security policy has been undergoing transformation in the 21 st century, especially with regards to how it views state sovereignty. One of the current features is a much more instrumental approach to realizing aims and goals as opposed to the ideational approach. Accordingly, two models of sovereignty in Russian foreign policy seem to coexist today- "post-Soviet" (with regard to the Near Abroad) and "Westphalian' (with regard to regions beyond the Near Abroad). They perform three functions in Russia's foreign policy today: 1) help secure Russian interests at the domestic, regional and international levels; 2) serve as a balancing mechanism against the U.S. and its allies, which are perceived as moving towards a postWestphalian model of sovereignty; 3) act as a marker of a 'non-Western' power identity in the emerging multipolar global order (Deyermond, 2016, pp. 958-959). The Arab Spring and especially the contradictions that emerged between the conception of the regime change as a "humanitarian intervention" and the principle of state sovereignty have caused Russia to assume a tough stance. 
In the wake of the events in Libya, then Prime Minister Putin stated that Russia "must not allow the Libya scenario to be reproduced in Syria" (Putin, 2012). This necessitated a more active position from Russia in the Syrian conflict that would go beyond diplomacy. Moscow chose to take a policy of what it termed as "active neutrality" in the Syrian conflict (Dasseleer and Gosset, n.d.). The idea of active neutrality was best described in an interview with Andrei Manoilo (via Facebook chat on July 22, 2019): "Russia will never fight on the side of al-Assad and protect him against enemies. Russia only fights against international terrorism at the official invitation of the Syrian government." In this quote, Russia positions itself as a powerful broker in the Syrian war but does so within the context of legal legitimacy that is lacking with countries seeking to act as powerful brokers in aiding regime change.

One of the factors that traditionally held back Russia's influence was the inability to protect its allies in the MENA region, as was exemplified by the U.S.-led regime change operations in Iraq in 2003 and Libya in 2011 (Russell, 2018, p. 9). Russia felt betrayed by the U.S.-led Western coalition when all its members supported the no-fly zone in Libya in 2011, which permitted NATO to attack government forces and led to regime change when it seemed that al-Gaddafi could take over the "opposition" forces (Erenler, 2012, p. 176; Hinnebusch et al, 2016, p. 12). The result of the overthrow of al-Gaddafi's regime was far direr than when he was in control of the country: human rights rapidly spiralled downwards and the country turned into a failed state, ultimately becoming a safe haven for terrorist groups. In fact, NATO's "well-intentioned" intervention increased the death toll in acts of violence tenfold (Kuperman, 2015, pp. 68-72). The huge gap between the words and deeds in the NATO-led regime change operation in Libya confirmed the fears of the true purpose of the Western "humanitarian intervention" concept.

Therefore, when the U.S. attempted to take a similar path to regime change in Syria by trying to secure a UN Security Council resolution, China and Russia vetoed it. Russia stood to lose its closest ally in the MENA region, naval facilities in Tartus, and economic 
and trade relations with Syria. There was also the calculation that with regime change there would be no smooth transition to pro-U.S. "democracy." Instead, chaos and radicalism were likely to spread across the MENA region and beyond (including Russia), while al-Assad was seen as an effective barrier to the spread of Sunni fundamentalism (Magen, 2011; Zvyagelskaya, 2014; Dannreuther, 2015; Lund, 2019, p. 18). In the changing world order and the emerging multipolar world, Russia's foreign policy interests and relationships started to gradually move away from the Western-centric focus to diverse regional relations, which has made the MENA region more attractive for many economic, political and security reasons (Stepanova, 2018). Various considerations-local, regional, and global-compelled Russia to get directly and overtly involved in the Syrian conflict.

An interview with Nikolai Sukhov in July 2019 confirmed the above reasons and revealed some other Russian interests and goals. They can be divided into global, regional, local, and internal. At the global level, Russian interests are multivariate, one of them being cooperation with the U.S. and Europe in fighting ISIS, but also as a tacit road to a rapprochement after the Crimean events. The involvement in Syria was also seen as a path to Russia's recognition as a global power.

Russia's perception of the world order is guided by three principles: first, a country's government cannot be replaced in an "abnormal" way; second, foreign powers may not carry out military intervention or arm any forces in a country without a legitimate request from its government; third, imposing sanctions is unlawful. At the regional level, Russia lost its influence in the MENA region with the collapse of the Soviet Union. Starting from 2000, it tried to resume its position there and the Arab Spring presented such an opportunity. Russia has two strategic allies in the region-Iran and Syria, and it is prepared to defend both. Today Russia's political and economic influence is growing, which is already paying dividends: the leaders of the MENA countries increasingly often visit Moscow. There is also the goal of preventing gas and oil supplies from Gulf countries to the Mediterranean by U.S. companies, which may undermine Russian oil and gas supplies to Europe. At the local level, the main goal is to 
support the current Syrian government politically and militarily to ensure it stays in power, thereby securing Russian military bases and economic contracts in the long run and further developing economic collaboration. The aspect of public opinion is also important: in Syria, Russia is seen as a great power.

In the practical terms of regional geopolitics, the events in Libya threatened Russia's credibility as an actor of note and, if not rectified, its influence in the MENA region would have evaporated after significant economic, political and diplomatic investments had been made in the first years of the 21st century. Russia's support of the Syrian government can be regarded as secondary to Moscow's greater domestic and foreign strategic interests (Dias and Freire, 2019, p. 179). According to Dmitry Trenin, Russia's political objective was to engineer a peace settlement that would protect its interests in Syria and in the entire region, generate durable political and economic ties, and reestablish its prominent place among the leading powers of international relations (Trenin, 2016 , p. 26). Some researchers asserted that Russia was unlikely to back the Syrian government with military assistance due to the lack of vital strategic interests and the fear of a Soviet-like Afghanistan scenario (Allison, 2013, p. 823). However, this thinking showed a lack of understanding of the local, regional, and global interests at stake, and Russia's growing political resolve to halt the erosion of its positions, not only in Syria but also across the region and the world.

\section{USE OF HARD POWER IN SYRIA}

In the summer of 2015 it seemed that the U.S.-led regime change goal was about to be successfully accomplished through the use of hard power by proxy forces armed and supported by the anti-Assad coalition of various international actors (such as Qatar, Turkey, UK, France, Saudi Arabia, and various armed non-state actors). Therefore, on September 30, 2015, Russia launched an air operation targeting antigovernment forces. Simultaneously, there came a surge in the number of Iranian and Shia forces acting on the ground. The defenses of the anti-government groups began to crumble and the Syrian government began to regain control over some of its national territory (Lund, 2018, 
p. 21). By 2018, some observers rated Russia as the dominant external actor in the Syrian conflict (Lund, 2018, p. 25).

When Russia became operationally engaged in Syria, some commentators forecast that this move would diminish its soft power and influence in the MENA region (Dannreuther, 2015, pp. 85-86; Rutland and Kazantsev, 2016). With hindsight, these negative forecasts have proven wrong, at least in the medium term. An important aspect to consider is a symbolic signal to the evolving system of international relations: by deploying and using military hard power in Syria, Russia undermined the de facto U.S. monopoly on the global use of military force that it has held since the end of the Cold War (Trenin, 2016, p. 26). The use of military-based hard power in Syria has been viewed and assessed differently by different actors with different interests.

From the Russian perspective, the military intervention was a success for several reasons. Russia was able to take a strategic advantage of an international policy vacuum that had been created by the increasingly wary Western public approach towards excessive use of military intervention in the MENA region. The decisive military action taken by Russia has elevated its status and significance as an external actor in the Middle East. However, this success has not stopped dire predictions, such as "Russia is perhaps facing an Afghanistan scenario of the 1980s, which sapped the Soviet Union's strength" (Rodgers, 2019). The traumatic memory of the Soviet Union's Afghanistan experience of 1979-1989 certainly did shape Russia's reluctance to deploy ground troops and its wariness of getting bogged down in a long war of insurgency (Pieper, 2019, p. 365). However, Israel regards Russia's involvement as significant because it "constitutes a new strategic paradigm in the Middle East and the international arena" and "will have significant implications for the balance of power and rivalries in Syria's civil war, and for the struggle between the superpowers for global influence" (Dekel and Magen, 2015). Russian experts also shared some similar assessments.

Such an observation was highlighted in further interviews as evidenced by two major strategic trends which evolved in 2018 and which can define Russia's policy towards the region. When Moscow 
entered the Syrian conflict, it had three primary goals: prop up the Syrian government, militarily defeat terrorist groups, and break through Western isolation. Russia understood the problem of the Syrian war from a threat-based approach. These goals have been substantially realized. The Syrian government is stable (to the point where the Syrian government can take a more independent approach from Russian advice); no terrorist groups pose a vital security challenge to Syria or Russia; Russia's bilateral strategic relations with MENA regional actors and the outreach of some "Western states to Moscow make the 'isolation' argument irrelevant" (interview with Maxim Suchkov via Facebook in August 2019). This observation prompts a conclusion that Russia's hard power capability has been converted to soft power capacity. The successful application of Russia's hard power potential to realize its local, regional, and global foreign and security policy goals has also been noted by other Russian political analysts (Aksenyonok, 2019, p. 21).

\section{SOFT POWER IN SYRIA}

Soft power and its operationalization in foreign and security policy were seen by Russia as a way to protect its international (and domestic) interests, and to counter what it regarded as the subversive use by the U.S. of political warfare against foreign countries (Rutland and Kazantsev, 2016, p. 396). In 2012, Putin defined soft power as "the promotion of one's own interests and approaches through persuasion and attraction of empathy (simpatii) towards one's country, based on its achievements not only in the material sphere but also in the spheres of intellect and culture" (Kremlin, 2012). Thus, the Russian picture fits into the debate mentioned above that Nye's vision of soft power was too U.S.-centric and needs to be reconsidered to meet the specificities of the Russian political environment and circumstances.

To a certain degree, the advantages of Russia's non-coercive military diplomacy in the MENA region owe to the United States' missteps and Russia's direct military involvement in the Syrian war. Russia managed-to some extent at least-to take the role of an external hegemon, which has resulted in greater regional influence and in a 
substantial increase of arms sales (Korybko, 2019). In 2005, Russia endorsed the World Summit Outcome declaration that envisages international recognition of the Responsibility to Protect (R2P) doctrine (Rae and Orchard, 2016, p. 1). However, the subsequent experience of the regime change during "color revolutions" and the Arab Spring also spurred Russia to mimic some aspects of Western "humanitarian intervention," which is seen in Russias approach to the $\mathrm{R} 2 \mathrm{P}$ doctrine. This has been labeled as being instrumental and at odds with the "international" understanding of R2P (Kuhurt, 2015; Rae and Orchard, 2016; Baranovsky and Mateiko, 2016). This logic is consistent with Ziegler's (2018) assessment of Russia's instrumental and multiple understanding of sovereignty in international relations.

Russia's approach to intervention and $\mathrm{R} 2 \mathrm{P}$ has been "framed within a largely rational argument rooted in statist international law" (Averre and Davies, 2015, p. 813). Russia regarded with suspicion a move that mirrored early events in Libya when the National Coalition of Syrian Revolutionary and Opposition Forces, which was promoted by the West as representing the Syrian people, but which actually included Islamist extremist elements and an Al-Qaeda affiliate, had one common goalregime change. Russia argued further that most of the Syrian people supported the Syrian government and were fearful of the consequences that would follow a Libya scenario in the case of regime change (Averre and Davies, 2015, pp. 819-820). These considerations led Russia to take a different path to the application of its R2P vision in Syria.

Contrary to common Western assessment that Russia's direct involvement in the Syrian conflict would reduce its influence and operational choices, Israel stated: "It seems that the opposite is the case. In place of the foothold it is losing in the Middle East, Russia is working to consolidate a new camp of supporters" (Magen, 2011, p. 3). This was subsequently confirmed in a European Parliament briefing.

Russia's success in imposing its agenda in Syria has bolstered its influence throughout the region. Although Russia's role is not always a constructive one, it has become a key actor and sometimes mediator in regional conflicts from Libya to Yemen. Russia's political clout in the region is also enhanced by its skillful use of energy cooperation to 
further its economic and geopolitical interests. Russia's drive to become a major Middle Eastern player should be seen in the wider context of global geopolitical rivalry with the United States. Moscow's growing influence in the region is as much the result of Western policy failures as of its own strength (Russell, 2018, p. 1).

One of the successes of Russian soft power in Syria is the ability to render the United States somewhat irrelevant through co-opting the international mediation role. From 2012 until December 2017, the U.S. monopolized the narrative of the Syrian conflict through peace talks in Geneva, which also served as the basis for its role as a powerful broker. This was done through subjectively picking and choosing which actors could or could not attend, and through rhetorically assigning blame. This was interrupted and eventually usurped by the Russian-led peace talks in Astana and Sochi. In this case Russia was in a position to assume the role of a powerful broker in the conflict (Kofman and Rojansky, 2018, pp. 21-23; Lund, 2018, pp. 36-37; Russell, 2018, pp. 2, 5, 9). Suchkov (in the 2019 interview) stated: "Ongoing talks with Iran and Turkey over 'American succession' in Syria show that the Astana format is the best venue for the three to discuss their own internal disagreements and push forward their respective agendas." These sentiments were echoed in a public statement to the UN Security Council by the Russian representative: "We will be doing so [to bring peace to Syria] in our national capacity, as a member state of the UN Security Council, and as part of the 'Astana troika' - the format that has done more than any other ones to achieve de-escalation in Syria, eliminate the terrorist threat, expand humanitarian assistance, and promote the political process" (Permanent Mission, 2019). So, Russia engages as a powerful broker but tends to not exclude significant local and regional players from the mediation process.

One of the successful mechanisms employed in the conflict was the use of negotiated settlements between government, anti-government, and international forces, where Russia acted as a broker. The groups were offered amnesties and deconfliction/de-escalation agreements that secured a way to avoid likely death that would have resulted from standing and fighting in isolated pockets (Lund, 2018, pp. 21- 
23). However, Russia has not always been successful in attempts to broker change in Syria. One such example was an attempt-made to alleviate criticism from the West and voiced in official and confidential conversations-to allow greater representation of the opposition in politics. However, this was rejected as "the current tide of the fortune of war was favoring the Syrian government" (Sukhov 2019 interview). This case demonstrates the reluctance to mediate when one side understands that it is winning the military conflict and therefore does not feel the need for political negotiation.

One of the reasons for Russia's relative success in the MENA region after the Syrian intervention is that it has adapted to and grasps more readily the growing role of regional processes and is prepared to engage regional actors on an equal footing (Stepanova, 2018). This is achieved through multiple partnerships, a non-ideological approach, pragmatism, and cultural relativism. These specifics-regionalization of politics and security in the MENA region-are something that the West has not been ready to adjust to (Kozhanov, 2016, pp. 97-100). Russia's success in the hard power field has paved the way for a softer power approach in the Syrian conflict.

According to Maxim Suchkov (2019 interview), Moscow is likely to pursue the initiatives it established in 2018 within the framework of three pillars: 1) creation of a constitutional committee; 2) the return of refugees; and 3) facilitation of the re-legitimization of the Syrian government and the pursuit of funding for re-building the country. To be successful, this strategy would require functional collaboration with different stakeholders, such as the United Nations Special Envoy for Syria and various regional powers (for human security and reconstruction funds). Suchkov noted that actors outside the immediate region, such as the EU, France, and other European countries, would be welcomed too. However, any collaboration would not deter Russia from seeking to realize its goals and the process would go ahead with or without these countries. By actively engaging in Syria and preventing what seemed at one point to be an "inevitable" regime change that the U.S.-led West framed within the Arab Spring, Russia managed to reverse its declining fortunes in the MENA region and perhaps even beyond. 
This article attempted to take an insight in the effects of and interactions between hard and soft power in the context of armed conflicts by studying the examples of the 2003 U.S. intervention in Iraq and the 2015 Russian intervention in Syria. The assumption was that the application and permissibility of hard and soft power approaches to warfare is related to the notions and values of "just war," especially to why and how a war is fought. The two case studies illustrate that soft and hard power within the context of warfare are not incompatible binary opposites but are rather elements of a spectral continuum as a form of ratio. The operationalization of this ratio has significant implications for the outcome of the interaction between hard and soft power tools used in warfare.

The U.S. attempted to use its soft power resource that had been built up over many decades to legitimize and enable the use of hard power against Iraq. Deceptive means were used to bring in the "representational force" before various stakeholders: the "threat" of terrorism and the need for "humanitarian intervention" were presented as justification (soft and hard power reasoning) of war and not the real intention of regime change. Due to the tactical approach lacking strategic vision, the U.S.-led military campaign in Iraq turned out to be a failure. The U.S. paid a very high price for the regime change in Iraq: its impact on U.S. soft power has been catastrophic, and its foreign and security interests have been undermined.

Russia articulated its hard security objectives from the very beginning of the military campaign, which have been partly realized through the application of military hard power with soft power tools used as supplementary means. The goal set by Russia-ensuring regime stability in Syria-has been successfully achieved through a collaborative approach (unlike the unilateral approach used by the U.S. in Iraq) and cooperation with other stakeholders, although various other challenges remain. Even though the Russian approach to ensuring regime stability in Syria contradicted some of the objectives of other regional actors (regime change), Russia's soft power potential has increased. This is evident in the renewed activities and positive 
diplomatic relations between Russia and countries of the MENA region. Thus, an honest application by Russia of hard power to meet security objectives has enhanced its soft power opportunities.

\section{References}

Aksenyonok, A., 2019. The Syrian Crisis: A Thorny Path from War to Peace. Valdai Papers, \#104. Moscow: Valdai Discussion Club.

Averre, D. and Davies, L., 2015. Russia, Humanitarian Intervention and the Responsibility to Protect: The Case of Syria. International Affairs, 91(4), pp. 813-834.

Baker III, J. A., Hamilton, L. H., Eagleburger, L. S., Jordan Jr., V. E., Meese III, E., Day O'Connor, S., Panetta, L. E., Perry, W. J., Robb, C. S. and Simpson, A. K., 2006. The Iraq Study Group Report: The Way Forward-A New Approach. New York: Vintage Books.

Baranovsky, V. and Mateiko, A., 2016. Responsibility to Protect: Russia’s Approaches. The International Spectator: Italian Journal of International Affairs, 51(2), pp. 49-69.

Bennett, W. L., Lawrence, R. G. and Livingstone, S., 2007. When the Press Fails: Political Power and the News Media from Iraq to Katrina. Chicago: The University of Chicago Press.

Bennis, P., 2003. Before and After: US Foreign Policy and the War on Terrorism. Northampton (MA): Olive Branch Press.

Bially Mattern, J., 2005. Why 'Soft Power' Isn't So Soft: Representational Force and the Sociological Construction of Attraction in World Politics. Millennium: Journal of International Studies, 33(3), pp. 583-612.

Boréus, K. and Bergström, G., 2017. Analysing Text and Discourse: Eight Approaches for the Social Sciences. Thousand Oaks (CA): Sage Publishing.

Borshchevskaya, A., 2019. Using American Soft Power to Counter Russian Influence in Iraq. Washington Institute [online]. Available at: <www. washingtoninstitute.org/policy-analysis/using-american-soft-power-counterrussian-influence-iraq > [Accessed 25 February 2021].

Bose, P. and Lyons, L. E., 2015. Soft Power and the Case of Iraq. Against the Current [online]. Available at: <againstthecurrent.org/atc176/p4417/> [Accessed 25 February 2021]. 
Dannreuther, R., 2015. Russia and the Arab Spring: Supporting the CounterRevolution. Journal of European Integration, 37(1), pp. 77-94.

Dekel, U. and Magen, Z., 2015. Russian Involvement in Syria: What Has Changed, and the Significance for Israel. INSS Insight, No. 752, Available at: $<$ www.inss.org.il/publication/russian-involvement-in-syria-what-has-changedand-the-significance-for-israel/> [Accessed 25 February 2021].

Deyermond, R., 2016. The Uses of Sovereignty in Twenty-First Century Russian Foreign Policy. Europe-Asia Studies, 68(6), pp. 957-984.

Dias, V. A. and Freire, M. R., 2019. Russia and the Arab Spring: A CounterRevolutionary Power in the MENA Region. In: Cakmak, C. and Özcelik, A. O. (eds.). The World Community and the Arab Spring. London: Palgrave, pp. 161-183.

Erenler, M., 2012. Russia’s Arab Spring Policy. Bilge Strateji, 4(6) Spring, pp. 167-191.

Frykskog, L., 2019. Soft Power Enables the Exercise of Hard Power. Swedish Defence University [online]. Available at: $<w w w . f h s . s e / e n / s w e d i s h-d e f e n c e-$ university/stories/2019-12-09-soft-power-enables-the-exercise-of-hard-power. html $>$ [Accessed 25 February 2021].

Gianotta, V., 2020. Soft or Hard Power: The Cycle of US Policy in the Middle East. Daily Sabah. Available at: <www.dailysabah.com/op-ed/2020/01/10/ soft-or-hard-power-the-cycle-of-us-policy-in-the-middle-east $>$ [Accessed 25 February 2021].

Gray, C. S., 2011. Hard Power and Soft Power: The Utility of Military Force as an Instrument of Policy in the 21st Century. Strategic Studies Institute: US Army War College.

Hinnebusch, R., Zartman, I. W., Parker-Magyar, E. and Imady, O., 2016. UN Mediation in the Syrian Crisis: From Kofi Annan to Lakhdar Brahimi. New York: International Peace Institute.

Hinnebusch, R., 2007. The US Invasion of Iraq: Explanations and Implications. Critique: Critical Middle Eastern Studies, 16(3), pp. 209-228.

Hyde-Smith, P., 2007. The Hard Road Back to Soft Power. Georgetown Journal of International Affairs, 8(1) Winter/Spring, pp. 115-123.

Kofman, M. and Rojansky, M., 2018. What Kind of Victory for Russia in Syria? Military Review, March-April, pp. 6-23. 
Korybko, A., 2019. Moscow's Military Diplomacy in the Middle East: A Major Headache for the US. American Herald Tribune [online]. Available at: <ahtribune.com/world/europe/russia/3309-moscow-military-diplomacy.html> [Accessed 25 February 2021].

Kounalakis, M. and Simonyi, A, 2011. The Hard Truth About Soft Power, Paper 5. CPD Perspectives on Public Diplomacy. Los Angeles: Figueroa Press.

Kozhanov, N., 2016. Russia and the Syrian Conflict: Moscow's Domestic, Regional and Strategic Interests. Berlin: Gerlach Press.

Kremlin, 2012. Soveshchanie poslov i postoyannyh predstavitelei Rossii [Meeting of Ambassadors and Permanent Representatives of Russia]. Available at: $<w w w$. kremlin.ru/events/president/news/15902> [Accessed 25 February 2021].

Kuperman, A. J., 2015. Obama's Debacle: How a Well-Meaning Intervention Ended in Failure. Foreign Affairs, 94(2) March/April, pp. 66-77.

Lund, A., 2019. From Cold War to Civil War: 75 Years of Russian-Syrian Relations. UI Paper, No. 7. Stockholm: Swedish Institute of International Affairs.

Lund, A., 2018. Syria's Civil War: Government Victory or Frozen Conflict? FOI-R-4640-SE. Stockholm: FOI.

Magen, Z., 2011. The Arab Spring and Russian Policy in the Middle East. INSS Insight, No. 282. Institute for National Security Studies.

Matlary, J. H., 2006. When Soft Power Turns Hard: Is an EU Strategic Culture Possible? Security Dialogue, 37(1), pp. 105-121.

Morozov, V. and Simons, G., 2019. Russia’s Public Diplomacy in the Middle East. In: Velikaya, A. and Simons, G. (eds). Russia's Public Diplomacy: Evolution and Practice. London: Palgrave MacMillan, pp. 233-256.

Moses, J., Bahador, B. and Wright, T., 2011. The Iraq War and the Responsibility to Protect: Uses, Abuses and Consequences for the Future of Humanitarian Intervention. Journal of Intervention and Statebuilding, 5(4), pp. 347-367.

Munslow, B., 2009. Loosing Soft Power in Hard Places: Humanitarianism After the US Invasion of Iraq. Progress in Development Studies, 9(1), pp. 3-13.

Nye, J. S., 2003. US Power and Strategy After Iraq. Foreign Affairs, 82(4), pp. 60-73.

Nye, J. S., 2004. Soft Power: The Means to Success in World Politics. New York: Public Affairs

Payne, K., 2005. The Media as an Instrument of War. Parameters, Spring, pp. 81-93. 
Hard and Soft Power Approaches to Armed Conflicts: The United States in Iraq and Russia in Syria

Permanent Mission, 2019. Statement by Permanent Representative Vasily Nebenzia at the UN Security Council Meeting on Syria, 30 July. Permanent Mission of the Russian Federation to the United Nations. Available at: < russiaun. ru/en/news/syria_hum3007> [Accessed 25 February 2021].

Pieper, M., 2019. 'Rising Power' Status and the Evolution of International Order: Conceptualising Russia’s Syria Policies. Europe-Asia Studies, 71(3), pp. 365-387.

Putin, V., 2012. Rossiya i menayustchiysya mir [Russia and the Changing World]. Rossiskaya Gazeta, 27 February [online]. Available at: <rg.ru/2012/02/27/putinpolitika.html> [Accessed 25 February 2021].

Rae, H. and Orchard, P., 2016. Russia and the Responsibility to Protect. AP R2P Brief, 6(1).

Rodgers, J., 2019. Russia and Syria: Policies, Problems, Perspectives. Forbes, 11 January [online]. Available at: <www.forbes.com/sites/ jamesrodgerseurope/2019/01/11/russia-and-syria-prospects-and-prizes/> [Accessed 25 February 2021].

Roth, K., 2006. Was the Iraq War a Humanitarian Intervention? Journal of Military Ethics, 5(2), pp. 84-92.

Russell, M., 2018. Russia in the Middle East: From Sidelines to Centre Stage. European Parliamentary Research Service, PE 630.293.

Rutland, P. and Kazantsev, A., 2016. The Limits of Russia's 'Soft Power'. Journal of Political Power, 9(3), pp. 395-413.

Select Committee, 2014. Select Committee on Soft Power and the UK's Influence. Chapter 3: Responding to Change: Hard, Soft and Smart Power. Publications. Parliament UK [online]. Available at: < publications.parliament.uk/pa/ld201314/ ldselect/ldsoftpower/150/15007.htm> [Accessed 25 February 2021].

Simons, G., 2008. Mass Media and the Battle for Public Opinion in the Global War on Terror: Violence and legitimacy in Iraq, Perceptions Journal,13, SpringSummer, pp. 79-92.

Steinberg, J. B., 2008. Real Leaders Do Soft Power: Learning the Lessons of Iraq. Washington Quarterly, 31(2), pp. 155-164.

Stepanova, E., 2018. Russia and Conflicts in the Middle East: Regionalisation and Implications for the West. The International Spectator: Italian Journal of International Affairs, 53(4), pp. 35-57.

Trenin, D., 2016. The Revival of the Russian Military: How Moscow Reloaded. Foreign Affairs, 23, pp. 23-29. 
Tsygankov, A., Tsygankov, P. and Gonzales, H., 2021. Putin's "Global Hybrid War": U.S. Experts, Russia, and the Atlantic Council. Russia in Global Affairs, 19(1), pp. 146-172.

Wagner, C., 2005. From Hard Power to Soft Power? Ideas, Interaction, Institutions, and Images in India's South Asia Policy. Heidelberg Papers in South Asian and Comparative Politics, Working Paper No. 26.

Wagner, J-P., 2014. The Effectiveness of Soft and Hard Power in Contemporary International Relations. E-International Relations. Available at: $<w w w . e-i r$. info/2014/05/14/the-effectiveness-of-soft-hard-power-in-contemporaryinternational-relations/> [Accessed 25 February 2021].

Western, J., 2005. Selling Intervention and War: The Presidency, the Media, and the American Public. Baltimore (MD): The Johns Hopkins University Press.

Wilson III, E. J., 2008. Hard Power, Soft Power, Smart Power, ANNALS, AAPPS, 616, pp. 110-124.

Ziegler, C. E., 2018. Russian Diplomacy: Challenging the West. Seaton Hall Journal of Diplomacy and International Relations, Spring, pp. 74-89.

Zollmann, F., 2017. Media, Propaganda and the Politics of Intervention. New York: Peter Lang. 